\title{
Production of High Performance Mountings by Using Rubber-Polymer Waste
}

\author{
Ali I. Al-Mosawi1 ${ }^{1}$ Abbass A. Hashim², Mohammed H. Al-Maamori ${ }^{3}$ \\ ${ }^{1}$ University of Miskolc, Miskolc, Egyetemváros, Hungary \\ ${ }^{2}$ Power of Technology Company, Sheffield, UK \\ ${ }^{3}$ College of Engineering Materials, University of Babylon, Iraq \\ Email: aliibrahim76@yahoo.com, director@es4td.co.uk, mhalmaamori1959@ya hoo.com
}

How to cite this paper: Al-Mosawi, A.I., Hashim, A.A. and Al-Maamori, M.H. (2019) Production of High Performance Mountings by Using Rubber-Polymer Waste. Open Access Library Journal, 6: e5368. https://doi.org/10.4236/oalib.1105368

Received: April 3, 2019

Accepted: April 23, 2019

Published: April 26, 2019

Copyright $\odot 2019$ by author(s) and Open Access Library Inc.

This work is licensed under the Creative Commons Attribution International License (CC BY 4.0).

http://creativecommons.org/licenses/by/4.0/

\begin{abstract}
Hybrid composite material consists rubber matrix reinforced by polymer waste stripes is introduced in this study. Hardness and adhesion of Acrylonitrile Butadiene Rubber-Polyethylene Terephthalate (PET) waste composite have been investigated. The study included the relationship between these properties and the percentage of PET'sadditives $(0-100 \mathrm{pphr})$ as a reinforcement material. The obtained results show that the rubber reinforced by PET waste is refining the Hybrid composite properties from engineering and economic aspect. With only $80 \mathrm{pphr}$ of PET waste additives, the rubber hardness improved by $28 \%$ and its adhesion improved by $18 \%$.
\end{abstract}

\section{Subject Areas \\ Composite Material}

\section{Keywords}

NBR-PET Composite, Rubber Mountings, Waste Recycling

\section{Introduction}

Unfortunately, many countries still do not have enough awareness to sustain their natural resources and recycling plan for waste's technology. The negative environmental effect of this type of waste which accumulates in thousands of tons is raising the percentage of pollution [1]-[9]. Figure 1 shows the exacerbate accumulation problem toward environmental pollution. However, there are so many countries implementing high performance recycling technologies, but there is still a shortage and a demand in dealing with recycling different types of waste composite materials. Plastic waste is very harmful, especially polyethylene 


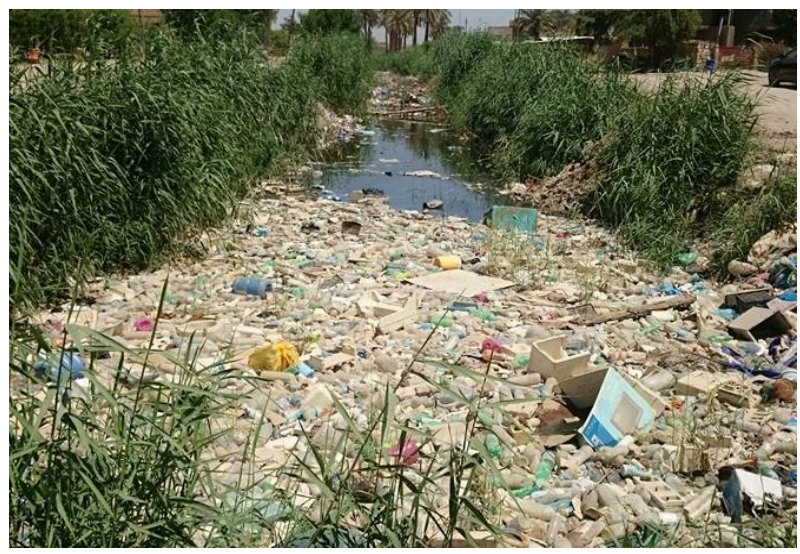

Figure 1. One of the sub-rivers suffers from plastic pollution (IRAQ).

terephthalate (PET). The long degradation time and decomposition are damaging landfill. Toward the plastic burning processing which has been developed recently to turn plastic into a fuel can be implemented for a short range of plastic waste type.

Therefore, the best solution to reduce the environmental damage of this waste is recycling and converting into a raw material or useful products. Developing this field of technology will contribute toward the development of sustainable environment and increase the population's awareness of using safe disposal methods in most of the countries [10]-[17].

The aim of this study is to subsidize plastic industry in two main areas:

1) Environmental sustainability by reducing environmental pollutants.

2) Economically as the manufacturing products from this waste is cheap comparing to the use of original raw materials and having the same mechanical properties, better in some instances.

\section{Methodology}

\subsection{Materials}

The raw materials used in this research and the pphr contents are illustrated in Table 1 and Table 2.

\subsection{Samples Preparation}

The first step, the raw materials in Table 1 (except PET) processed by using a rolling Comerio Ercole Busto Avsizo roll mill machine, which contains two rolls with $150 \mathrm{~mm}$ diameter and $300 \mathrm{~mm}$ length rotating with $24 \mathrm{rpm}$ speed to produced rubber sheets. The second step, using hydraulic compression machine to produce the multilayer mountings samples from rubber sheets and PET strips.

\subsection{Testes and Samples Standards}

a) Adhesion test: To calculate the adhesion force between rubber and PET 
Table 1. Material used and their proportion.

\begin{tabular}{cc}
\hline Compounding Ingredients & Content (pphr) \\
\hline Acrylonitrile butadiene rubber (NBR-30\% AN) & 100 \\
Polyethylene terephthalate (PET) & $0-100$ \\
Carbon black & $0-40$ \\
Zinc oxide & 3 \\
Sulfur & 1.5 \\
Antioxidant (6PPD) & 1.5 \\
Accelerator (TMTD) & 1.5 \\
Plasticizer (DOP) & 1 \\
Stearic acid & 1 \\
\hline
\end{tabular}

Table 2. The percentage of PET hardener used in this study.

\begin{tabular}{ccc}
\hline Rubber compound recipe (pphr) & $\begin{array}{c}\text { PET } \\
\text { Hardener Percentage }\end{array}$ & PET (pphr) \\
\hline 0.66 & 0 & 0 \\
0.589 & $20 \%$ & 11.6 \\
0.552 & $40 \%$ & 20.77 \\
0.47 & $60 \%$ & 28.2 \\
0.443 & $80 \%$ & 34.4 \\
0.39 & $100 \%$ & 39.6 \\
\hline
\end{tabular}

layers, the Tensometer T10 device was used for this purpose according to the ASTM D429-14 standard [18].

b) Hardness IRHD test: this test was done according to ASTM D2240-15e1 [19] by using Wallace bead load hardness instrument.

\section{Results and Discussions}

Figure 2 represents the Adhesion test of NBR-PET mounting composite, we can observe from this figure that adhesion between rubber and PET layers increased with increments of PET content because the grooved edges of the PET strips layers act as high bonding points with rubber matrix. The increment in adhesion starts to decrease when the PET additives exceed 80 pphr due to the low percentage of rubber between PET strips making it easy to separate from matrix. The additives help to increase rubber hardness in general because it is a highly elastic material. The adhesion is improved by $18 \mathrm{~N}$ up to the optimum percentage point (OPP) with an improvement rate (IR) of $22.5 \%$.

Figure 3 represents the hardness test of SBR-PET mounting composite. Obviously, the relation is positive between the PET waste percentage and hardness, so the hardness increases with the increase of PET percentage [10] [16]. The average improvement Rate is $30 \%$. 


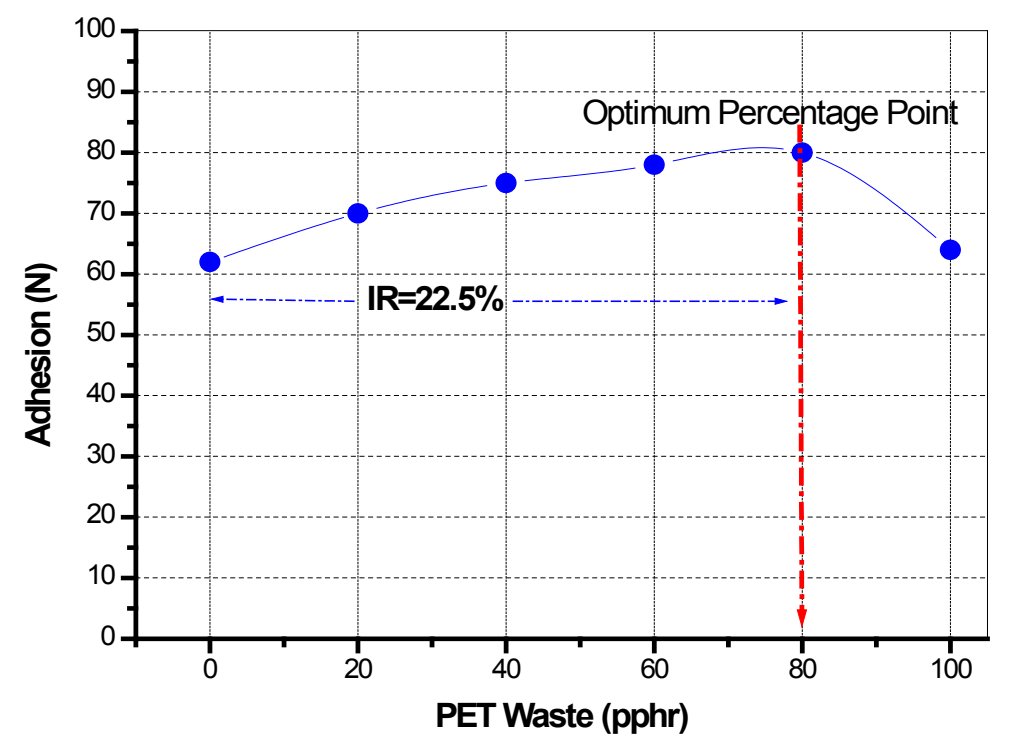

Figure 2. Adhesion test of NBR-PET mounting composite as a function of PET waste content.

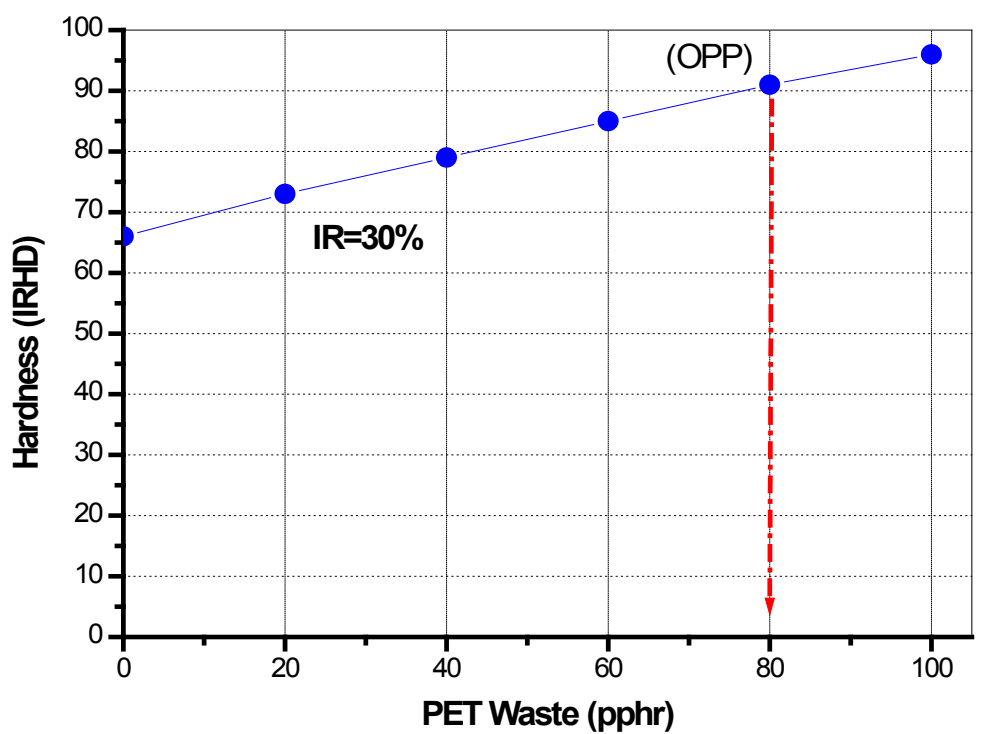

Figure 3. Hardness test of NBR-PET mounting composite as a function of PET waste content.

\section{Conclusion}

After analyzing the results obtained from the tests, we found that there is an advantage for using PET waste in engineering applications, including the mountings production. The rubber hardness is improved when adding these wastes to rubber, being better bonded between the layers of PET waste and rubber. The optimum ratio of PET waste additives is $80 \mathrm{pphr}$, to achieve the best balance between hardness and adhesion.

\section{Conflicts of Interest}

The authors declare no conflicts of interest regarding the publication of this paper. 


\section{References}

[1] Al-Mosawi, A.I. and Abdulsada, S.A. (2015) Recycling of Waste Materials: A Review. 1st Edition, LAP Lambert Academic Publishing, Germany.

[2] Dhir, R.K., Newlands, M.D. and Halliday, J.L. (2003) Recycling and Reuse of Waste Materials. 1st Edition, ICE Publishing, London.

[3] Al-Mosawi, A.I., Abdulsada, S.A. and Rijab, M.A. (2017) Recycling Procedure of Plant Waste for Manufacturing Green Composite Material. International Journal of Engineering Technology, Management and Applied Sciences, 5, 211-214.

[4] Bolden, J., Abu-Lebdeh, T. and Fini, E. (2013) Utilization of Recycled and Waste Materials in Various Construction Applications. American Journal of Environmental Science, 9, 14-24. https://doi.org/10.3844/ajessp.2013.14.24

[5] Abdulsada, S.A. and Al-Mosawi, A.I. (2015) Tensile Strength of a New Recyclable and Environment Friendly Composite Material. Ciência e Técnica Vitivinícola, 30, 32-40.

[6] Rijab, M.A., Al-Mosawi, A.I., Abdulsada, S.A. and Ajmi, R.K. (2015) Recycling of Aluminum Castings Waste. EC Chemistry, 1, 4855.

[7] Al-Salem, S.M., Lettieri, P. and Baeyens, J. (2009) Recycling and Recovery Routes of Plastic Solid Waste (PSW): A Review. Waste Management, 29, 2625-2643. https://doi.org/10.1016/j.wasman.2009.06.004

[8] Rijab, M.A., Al-Mosawi, A.I. and Abdulsada, S.A. (2015) Recycling of Aluminum Solid Waste in Diyala Company for Electrical Industries. International Journal of Innovative Research and Creative Technology, 1, 44-47.

[9] Al-Mosawi, A.I., Ali, M.M. and Abdulsada, S.A. (2015) Theoretical Approach to Tensile Strength of Composite Material Reinforced by Recycled Cellulose Fibers. Fire Journal of Engineering and Technology, 1, 42-45.

[10] Al-Mosawi, A.I. and Abdulsada, S.A. (2018) Technological Procedure for Recycling of Pet Waste for Sustainable Environment Concept Achievement. Open Access Library Journal, 5, e4327. https://doi.org/10.4236/oalib.1104327

[11] Worrell, E. and Reuter, M.A. (2014) Handbook of Recycling, 1st Edition, Elsevier, Amsterdam, Netherlands. https://doi.org/10.1016/B978-0-12-396459-5.00001-5

[12] University of Cambridge (2005) The ImpEE Project, Recycling of Plastics.

[13] Malik, N., Kumar, P., Shrivastava, S. and Ghosh, S.B. (2017) An Overview on PET Waste Recycling for Application in Packaging. International Journal of Plastics Technology, 21, 1-24.

[14] Sun, C.-H., Chen, X.-P., Zhuo, Q. and Zhou, T. (2018) Recycling and Depolymerization of Waste Polyethylene Terephthalate Bottles by Alcohol Alkali Hydrolysis. Journal of Central South University, 25, 543-549. https://doi.org/10.1007/s11771-018-3759-y

[15] López-Fonseca, R., Duque-Ingunza, I., De Rivas, B., Arnaiz, S. and Gutiérrez-Ortiz, J.I. (2010) Chemical Recycling of Post-Consumer PET Wastes by Glycolysis in the Presence of Metal Salts. Polymer Degradation and Stability, 95, 1022-1028. https://doi.org/10.1016/j.polymdegradstab.2010.03.007

[16] Al-Maamori, M.H., Al-Mosawi, A.I. and Abed, M.A. (2015) Design and Manufacture of Road Bumps Using Waste of Polyethylene Terephthalate Bottles (PET). Patent No. 4244.

[17] Ashter, S.A. (2014) Thermoforming of Single and Multilayer Laminates: Plastic Films Technologies, Testing, and Applications. 1st Edition, William Andrew publishing, Elsevier, Amsterdam, Netherlands. 
[18] ASTM International (2014) ASTM D429-14, Standard Test Methods for Rubber Property-Adhesion to Rigid Substrates. West Conshohocken, PA.

[19] ASTM International (2015) ASTM D2240-15e1, Standard Test Method for Rubber Property-Durometer Hardness. West Conshohocken, PA. 